\title{
Interculturality and Sport: Mediatization of Culture Contact in Reporting Euro 2012 by the British and Irish National Press*
}

\author{
Międzykulturowość a sport: mediatyzacja kontaktu kulturowego
} w doniesieniach prasy brytyjskiej i irlandzkiej na temat Euro 2012

Streszczenie: Sport uważa się za uosobienie procesów międzykulturowych dzięki łączeniu ludzi w zgodnych działaniach przy jednoczesnym generowaniu konfliktów między nimi. Ta dwoistość sportu często znajduje odbicie w medialnych sprawozdaniach z imprez sportowych. Niniejszy artykuł przedstawia rezultat badań nad tekstami w prasie brytyjskiej i irlandzkiej poświęconymi finałom Mistrzostw Europy w piłce nożnej (Euro 212) rozgrywanym w Polsce i na Ukrainie, prowadzonych pod kątem ich międzykulturowego oddziaływania. Ton doniesień w gazetach pochodzących z dwu sąsiednich krajów i często należących do tych samych koncernów okazał się bardzo różny. Prasa brytyjska nie dostrzegła obszarów kulturowego zbliżenia między gospodarzami a gośćmi mistrzostw, przyjmując taktykę powielania znanych swoim czytelnikom historycznie utrwalonych stereotypów kulturowego i cywilizacyjnego zacofania Europy Wschodniej. Relacje o kulturowej interakcji Polaków i Irlandczyków zamieszczane w prasie irlandzkiej, choć w większości bardzo pozytywne, także opierały się na stereotypach i banalnych uogólnieniach o obu nacjach. Badanie wykazało, że zarówno doniesienia w prasie brytyjskiej, jak i w irlandzkiej rządziły się wewnętrzną logiką i interesami tych mediów, a nie troską o jakość efektów międzykulturowych.

Słowa kluczowe: piłka nożna, mistrzostwa Europy w piłce nożnej 2012, międzykulturowość, prasa brytyjska, prasa irlandzka, medialne przedstawienia Europy Wschodniej

The concept of interculturality has proved beyond doubt to be much more than a mere intellectual fashion of the recent decade. It became a relevant analytical

\footnotetext{
* Research for this paper was financed with the grant from the National Science Centre Poland (NCN) no. 2012/05/B/HS2/04096.
} 
category which provides a useful perspective in analyzing the consequences of the accelerated forms of globalization and gave foundation to a dynamic crossdisciplinary field of inquiry known as intercultural studies. With a complex genesis, and being well-established by now in a number of disciplines and crossdisciplinary research areas, as well as in the professional practice of public and private institutions, interculturality is not easy to define precisely (Lavanchy, Gajardo and Dervin 2011: 1-28). Yet the polysemy and ambiguity of the term lamented by some scholars do not prevent others from efforts to clarify it as an epistemological category. Most practitioners of intercultural studies would agree with the proposition that interculturality involves people's confrontation with cultural otherness and responding to the difference in a dynamic way; that it means not just bringing members of different cultures together, but involves a degree of interaction between individuals, groups, and organizations resulting in a heightened awareness of the Other and seeing one's own culture in a different perspective (Rozbicki 2015: 1-5). Hence, intercultural engagement is "penetration of the Other's system: getting out of oneself to see things from the Other's perspective," "an attitude of opening up, a personal effort of inquiry" accompanied by the ability of negotiating the differences, i.e. "agreeing about a common minimum of values and ways of looking at things" (Interculturality"). Despite the prevailing tendency, especially in educational contexts, to associate interculturality with the positive processes of overcoming cultural difference, establishing new communication and improving social interaction, some authors also point out that "[c]ultural distance may be regarded as a negative aspect of intercultural communication" and that prior negative experience between intercultural partners may result in a failure of communication interactions between them (Koegeler-Abdi and Parncutt 2013: 6; Cai and Rodríguez 1996-7).

Interculturality acquired new prominence in public discourse when it started being juxtaposed with the concept and policy of multiculturalism. A survey of the recently published works discrediting multiculturalism for excessive preoccupation with cultural diversity and advocating interculturalism, as well as those treating the two approaches as complimentary (Barska, Korzeniowski 2007; Śliz, Szczepański 2011; Rattanasi 2011; Barrett 2013) reveals that their authors tend to treat interculturalism as a policy of managing cultural diversity and avoid reflection on theoretical and epistemological aspects of the phenomenon of interculturality in general. Parallel to such politicized debates, vigorous research on interculturality goes on within narrower disciplinary paradigms, most notably in the fields of linguistics, education, sociology and psychology (Szerląg 2013; Aman 2014; Piller 2011; Scollon, Scollon, Jones 2012; Otten 2009). Some much needed attempts have been made at overcoming this fragmentation 
and integrating the dispersed insights into a solid theoretical foundation of intercultural studies (Dervin, Gajardo and Lavanchy 2011; Rozbicki 2015), yet a lot remains to be done to overcome disciplinary and institutional constraints to capture the dynamics of the intercultural process and identify its universals.

In response to the call for interdisciplinary initiative in the study of interculturality as process, the present study proposes to examine it through the compound lens of sport, media and cultural studies. The following assumptions justify this particular intersection. Sport is often presented as a unifying social practice, a means through which the people of different nations, classes, cultures and perspectives are brought together in unison. At the same time, tension and conflict pervade sport. Within nation-states, and between nations, sport functions to separate people, to generate difference and to celebrate it. Across Europe, and globally, such tensions are omnipresent in numerous and differentiated ways (Bairner 2001; Maguire 2005; Dmowski and Szałański 2012). This coexistence of unity and discord makes sport the epitome of interculturality in action.

These are especially sports mega-events, such as the Olympic Games, FIFA World Cup finals, or UEFA Euro Championships that provide a wide platform for intercultural processes to occur. Maurice Roche defines mega-events as "large scale cultural (including commercial and sporting) events, which have a dramatic character, mass popular appeal and international significance" (2000: 1). Although research into sports events is largely concerned with their management, many studies are available of the social and cultural impact of megasport spectacles (Getz 2007; Richards, de Britto, Wilks 2013; Dashper, Fletcher, McCullough 2014). However, the intercultural aspect of large-scale sporting competitions has not been a major research theme yet (Roche 2000; Manzenreiter and Spitaler 2010).

It is significant that the mass-scale character, competitive nature, emotional atmosphere and national symbolism of large sporting events provide a framework within which members of different nations and ethnic groups come together, become exposed to cultural difference and engage in cross-cultural comparisons. Sports rivalry leads to an immediate contact among players and fans, with national teams symbolically representing national groups. Activating the existing concepts of "Otherness," mega sport events may result in strengthening the convictions of one's group superiority and endorsement of negative stereotypes, but may also reveal or confirm similarities among ethnic groups and reinforce a sense of affinity. Anyhow, they have a huge potential for intercultural engagement, as sport competition is possible only after some differences are negotiated. Moreover, in order to become culturally meaningful, sporting national rivalry requires from fans and observers an open attitude and an effort 
to understand who the Others (as represented by fans, sportspersons, national teams, or host nations) are. International sport organizations are indeed interested in the promotion of interculturality as a process which can facilitate smooth staging and progress of global competitions. The associations such as UEFA actively construct frameworks for intercultural interactions in order to make their sport events successful in organizational and financial terms (UEFA 2013)

The symbolic and cultural potential of sporting spectacles for interculturality derives not just from the immediate contact among fans and players, but also from their rich rituals which give visibility to national symbols, and from the expressive rhetoric accompanying both the preparation for the events and the competitions themselves. The factor additionally complicating the study of interculturality in sport is its inextricable connection with the media, whose discourse "is powerful enough to create and regulate individual and collective ideas and to target peoples and groups in multicultural, global and interconnected societies" (Gonçalves, Carpenter 2013 xiii-xiv). For most people it is not the immediate experience, but the mediation of the press, television, and the internet that determines the quality of sporting intercultural interactions. The finding that sport is the most common news topic in the mass media around the world adds extra validity to this claim (Shoemaker and Cohen 2006: 37-48).

A typical mega-event "draws international visitors and mass media interest" (Falkheimer 2007: 1). The international character of sporting rivalry creates demand for the news about the competition and its context, activates discourses of national identity and national myths, in which the images of other countries and nationalities play an extremely important role (Roche 2010; Manzenreiter and Spitaler 2010; Horne and Manzenreiter 2006). These narratives offer sporting audiences cultural knowledge about the involved countries and nations, enable cognitive interculturality and determine the tenor of potential situational interaction with "strangers" by influencing attitudes and shaping preconceptions. Therefore, the practice of interculturality in the context of sports events should also be studied in its media representations, not only because so many people are involved in such non-direct forms of participation, but also because it is to a large extent dictated by media interests and agendas.

The purpose of the present study is to analyse the British and Irish press coverage of the 2012 UEFA European Championship (Euro 2012) finals held in Poland and Ukraine as an example of a mediated practice of intercultural engagement and to assess its outcome. It is argued here that the tenor of the reporting was strikingly different in the newspapers produced in two neighbouring countries and often owned by the same media corporations. An attempt 
is made at explaining the difference in terms of the basic attributes of the intercultural practice: its historical character, its intrinsic ethnocentricity and constructiveness.

\section{Material and Method}

The present case studies are based upon newspaper articles dealing with Poland and Ukraine as co-hosts of Euro 2012 in the British daily and Sunday press in about nine months before the finals, the majority of which appeared in the pre-event weeks (May and early June 2012) and concurrently with the event (June 8 - July 1, 2012). In the part related to Kraków (the tournament base of the England team), the study sample is made upon 220 newspaper articles devoted entirely or partly to the city, while the part discussing the racism and hooliganism journalistic scare involves additional 30 articles. The research of the Irish press was based on 150 articles from the Irish national, regional and local newspapers published in 2012, and a few relevant articles which appeared between 2007 and 2013. The article corpus was collected searching the Nexis database and includes the electronic versions of the texts which were published both in the print and online versions of the papers. Each article was counted only once, i.e. identical or almost identical versions appearing in regional editions and in daily online updates of the same paper were eliminated. The analytical methods of close reading and content analysis were applied in order to identify the dominant and secondary topics in the coverage of the two countries. They were supplemented with discourse and textual analysis in search for more nuanced meanings and implicit ideological messages conveyed by the texts as well as journalistic framing of the reported places (Fowler 1991; Van Dijk 2001, 352-371; Wodak and Meyer 2006; Richardson 2007).

\section{Euro 2012 in the British press}

The British national papers laid very specific foundations for the intercultural process by their coverage of Euro 2012, particularly in the build-up period. A good example of the dominant journalistic drift was the reporting of Kraków, the city that did not host any matches, but was nevertheless selected by three European teams as a tournament base. The short stay of the England squad in Kraków increased its newsworthiness observed already in November 2011. Soon the reporting of Kraków was dominated by three themes: the condition of the 
Hutnik FC stadium designated as England's training ground, the "Stary" Hotel where the team were accommodated, and the cultural programme of the players and their women in Kraków. Both the qualities and the populars lamented the unsatisfactory condition of the stadium and repeatedly stressed the need of a major renovation. The $i$-Independent found the site forlorn and dilapidated (November 8, 2011), while the Daily Star of the same day called it a "muddy hell," totally unsuitable for "England's millionaire squad" and jeered at a picture of John Paul II abandoned in one of the cramped dressing rooms. The choice of the Stary Hotel by Fabio Capello as England's Kraków residence did not please all the journalists. While most of them acknowledged the luxury standard of the place, many could not resist making stinging comments on it: that the hotel had a Polish library stocked with the recent issue of an English-language mining journal (The Telegraph, November 7, 2011, emphasis added); that "one disgruntled customer gave it one star, calling it a 'let-down"' (The Guardian, November 7, 2011); that every hour round the clock "a bugler plays a 30-second tune from a church tower next to the team hotel" (MailOnline, June 6, 2012), which may interrupt the footballers' peace (The Mirror, June 7, 2012).

One might expect that England's plan to embrace the local culture would be used by the British journalists to engage the readers in more informative reporting of Poland - or at least Kraków - but it became just another opportunity for rehearsing in-group concerns, jokes and anecdotes. The PR idea of the players meeting the locals informally while strolling in the Old Town was dismissed as having "undeniable potential for misadventure" (The Guardian, November 8, 2011). Although informative tourist-targeted texts and paragraphs on Kraków's history, cultural heritage and culinary attractions started appearing in the press since May 2012 (Daily Star, May 7, 2012; Telegraph, May 10 and 24, 2012; MailOnline, May 18, 2012), and some much earlier (The Times, October 12, 2011; Telegraph, October 13, 2011), the tabloids stuck to sensationalized negative reporting of the fan campside fit "for tramps", "sky high" airfares, hotel prices that "have gone through the roof," "mafia-trained beauties ... intent on fleecing poor lonely English blokes of every penny" (Daily Star, May 23, 2012), the roads "either like farm tracks or covered in potholes and cracks" (Daily Star, June 3, 2012) and - worst of all - the dreadful "drying-out clinics" for drunken persons taken there forcibly by the police to sober (Sunday Mirror, June 3, 2012).

As the arrival of England at Kraków was approaching, The Sun introduced a new sensational thematic cluster, that of football hooliganism, racism, antiSemitism and neo-Nazism rampant in the city, named by the paper as the "City of the Knives." Thus, as "the powderkeg atmosphere" was allegedly building up in Krakow, the international footballers "braced themselves for a hellish reception 
- from home-grown Polish YOBS" and "innocent supporters [were] under threat of being permanently deafened by Polish cops wielding antihooligan 'sonic cannons'," the same type the US Navy used in Iraq (The Sun, May 8, 2012). The widely reported and commented instance of intercultural contact was the episode of monkey chants experienced by the Holland team from some spectators during the training session at the Wisła FC stadium. The Telegraph devoted 3 articles to the incident on two consecutive days (June 7 and 8,2012) and the Mail published its own report with the dramatic headline "Dutch a target of Poles' racist abuse with stars subjected to vile monkey chants" (MailOnline, June 7, 2012). The scale of the incident is hard to judge objectively, as even the Mail admitted that "[N]ot all the Dutch journalists heard the chanting" and failed to report it (ibid.). By comparison, the "noisy and friendly" reception of the English players by the Krakovians on their arrival to the city was briefly noticed only once by The Telegraph (June 7, 2012).

The topic of neo-Nazi and racist hooliganism in Poland and Ukraine surfaced as a special object of intense journalistic fearmongering in scary stories of racial hatred and violence in the pre-event weeks and concurrently with the event, when it was triggered by British television. First, Sky Sports News broadcast the "Ukraine's Hooligans" video in their Special Report on May 15, which uncovered a scary culture of Shakhtar Donetsk fans with neo-Nazi links. Within days, newspaper articles started appearing about the report's negative effect on the families of non-white England footballers. The Sky video turned out to be a mere overture to another piece of investigative television journalism, the 30-minute BBC One Panorama documentary Euro 2012: Stadiums of Hate broadcast during prime time, 11 days before the kick-off of the Championships (May 28, 2012). The reporter Chris Rogers and his team revealed shocking new evidence of racist violence and anti-Semitism at the heart of Polish and Ukrainian football. The climactic scene involved Sol Campbell, a former England footballer of Jamaican origin, delivering his famous piece of advice to the fans to stay home and watch the tournament on TV, because they "could end up coming back in a coffin." Almost instantly an avalanche of articles appeared in the British newspapers devoted to neo-Nazi and racist violence endangering football fans in Poland and in Ukraine. Eight dailies ran short and longer pieces on the subject in their print and several on-line editions, including The Guardian, which predicted a Euro 2012 disaster in Ukraine on its front page (May 29, 2012). Without exception, they all evoked the Panorama documentary as their source of evidence, in many cases the only one, not verified by any independent journalistic inquiry. Sol Campbell made many tabloid headlines and won fame as an expert on footballrelated violence in the two countries (telegraph.co.uk, May 28, 2012; The Sun, 
May 28, 2012; The Mirror, May 28, 2012). His “coffin" warning was quoted by all newspapers over and over again for days to come.

Another effective strategy of feeding hysteria over vicious racism in the host countries involved personal testimonies of some witnesses and victims of racial abuse, particularly in Ukraine (The Express, May 29, 2012; MailOnline, June 3, 2012). A few other satellite topics woven into the sports news in the build-up to the tournament extended football-related racism onto other instances of human rights abuse in the two countries: "a show trial" and mistreatment of the former Ukrainian Prime Minister Yulia Tymoshenko (The Times, June 7, 2012; The Daily Telegraph, June 8, 2012), "thousands of human rights abuses visited on ordinary Ukrainians every year" and "the widespread use of torture by a corrupt and out of control police force" (Independent.co.uk, June 5, 2012) as well as "the generally intolerable life of homosexual persons in those and other post-Soviet states" (The Times, June 7, 20123; The Express, May 29, 2012).

Thus the British print media discourses of Poland and Ukraine in the context of Euro 2012 demonstrated that hosting a big international sport event does not naturally lead to a positive intercultural effect. Sensational reports of infrastructure deficiencies (Kraków), corrupt and unreliable systems of law and order, pervasive racism, anti-Semitism and homophobia in Ukraine and Poland outnumbered and overshadowed a few balanced informative pieces of journalism devoted to the organizational effort, enthusiasm, cultural heritage, social life and tourist attractions in the two countries. The resultant misrepresentation of the Euro 2012 hosts acted as an impediment to interculturality on the part of the British reading public.

\section{Euro 2012 in the Irish press}

The intercultural experience of the visiting Irishmen and Irishwomen in Poland was an important theme in the Irish press reporting of Euro 2012. As the Republic of Ireland team lost three matches and failed to qualify for the knock-out stage of the tournament, the reporting focused on the behaviour of the Irish fans, the Green Army, and their intercultural encounters. The theme of Euro 2012 was linked to the defining of the fans' experience as a riotous football carnival, in which the locals shared fun with the visitors. Moreover, the press presented Polish hosts as a community of friendly and hospitable people and stressed the Irish-Polish cultural proximity.

The major way in which Euro 2012 is presented as intercultural experience for Irish fans is through the theme of play and fun. Irish Independent referred 
to "hedonistic weeks in Poznan ..., clouded by late nights, raucous sing-songs and lashings of beer" (July 20, 2012). An article in Irish Daily Mail described the fan zone in Poznan as "absolutely hopping before the match on Monday, with a barbecue roaring, beer flowing and Irish, Italian and Polish fans dancing and singing" (June 20,2012). Polish cities were described as stages for huge, wild parties, part of alcohol-fuelled football carnival, in which friendly Poles and fans of the Croatian and Spanish teams enjoyed themselves together with the Irish (Irish Examiner, June 8, 2012; The Mirror, June 13, 2012, Eire Edition). The newspapers admired the "craic," the Irish culture of fun, entertainment, and enjoyable conversation, which was shown not only before the matches, as illustrated by the extract below, but also after the painful defeats of their team.

On the main square in Poznan people have been drinking all day, climbing poles and singing, supping unclean water from the fountain. [...] The faces of Ireland and Croatia fans are pressed up weirdly against the glass in overstuffed olde worlde trams bound for the stadium, their hands are banging the ceilings, and a thrilling din of football song is spilling into the street. Local people are impressed and they take photographs of the squashed, singing creatures. At the tram stop near the square the atmosphere is uncomfortably close to fever pitch. Both sets of fans are here, and the singing exchanges are friendly, but there is a booze-driven wildness too (The Irish Times, June 16, 2012).

The Irish press often focused on the friendliness and hospitality of local Poles, the apparent Polish-Irish solidarity, and easy mutual understanding. Sunday Mirror claimed that "[e]verywhere our fans have gone they have been welcomed with open arms" (June 10, 2012, Eire Edition). Reporting on the Irish fans leaving Poznań, Irish Daily Mail noticed that "locals donned our colours in solidarity with their new friends" as "an open farewell to their adopted brothers from Ireland" (June 19, 2012). A lead in Kerryman said "P is Poznan. The Polish city that fell in love with the Irish and that the Irish fell in love with during Euro 2012" (January 2, 2013).

These accounts strengthened the pre-existing Irish assumptions about the cultural proximity of the Irish and Poles. On the arrival of the Republic of Ireland team in Poland FAI chief executive John Delaney said "We know that you will be following the Poland team in the Euros but we would like you to make Ireland your second team when Poland are not playing. There's a great connection between the Polish people and the Irish people" (Irish Daily Mail, June 6, 2012). The same ideas were also identified in the statements from Polish officials: Mikołaj Piotrowski, Polish spokesman for Euro 2012 said that Poles "[are] 
looking forward in particular to greeting Irish fans because we know we are very alike, loud and cheerful" (The Irish Times, June 2, 2012), while the mayor of Poznań, Ryszard Grobelny, welcomed the Irish as "kindred spirits" (Irish Examiner, June 7, 2012).

The mutual bonds between Ireland and Poland mentioned in the articles covering Euro 2012 include a common religion, a similarly tragic history of opposition to foreign oppressors, a more recent history of Polish immigration to Ireland, a tendency to be fatalistic and to oppose authority, the significance of family and community, the central role of alcohol in social rituals, easy bonding, and lack of prejudice. For the Irish, the host nation was described as their "Catholic cousins in Poland" (The Irish Times, December 3, 2011), and the fact that Poland is a Catholic nation was interpreted as a feature with which the Irish visitors could easily identify:

PRAISE be! Churches on Poland's Baltic coast are to hold Mass in extra languages to accommodate foreign football fans. [...] Roman Catholic mass will be said in English, Croatian, Spanish, German and Italian at 10 different churches in and around Gdansk on June 10,17 and 24. Irish fans, who will be based in the city for the clash with Spain on June 14, will have a chance to say a few Rosaries before the team takes on the world champions... (Irish Daily Mail, June 8, 2012).

The articles also suggested that parallel histories and the similarities in the cultural ethos between the Irish and Poles help to develop mutual understanding and close rapport. The Irish Times quoted historian Norman Davies who said that "Poles have a very solid apprenticeship in surviving adversity" and it was added that "[t]hat's a quality the Irish can relate to" (December 3, 2011). An article in Irish Daily Mail published a few weeks before Euro 2012 stated that "[t]he Poles, as we know from our own recent exposure to them, are very like the Irish; they have a fatalistic streak that is highly amusing" (May 10, 2012).

Another aspect of the press mediation of interculturality is the spread of general knowledge about Poland. The press offered a well of new information, starting with the so-far unfamiliar geographical names: the cities of Poznan and Gdańsk were the venues of the matches of the Republic of Ireland team, while Sopot was the place where the Irish team resided during the championships. Poland was shown to be a modern and (newly) Western country with a rich history, overcoming its Communist past. Poles were presented as a nation which has undergone a cultural, political and economic shift towards Western values and free market economy, the transformation which was also spurred also by the organization of Euro 2012 ("Euro 2012 is the perfect chance to consign the last 
strips of the iron curtain to the scrap heap of history," The Irish Times, December 3, 2011). A journalist from The Irish Times was "beguiled by the extent to which modern Poland is up and running, full steam ahead" and added that "[a]s you walk around the cities of Gdansk, Cracow, Poznan and Warsaw, modernity hits you in the face" (June 26, 2012).

With the football tournament approaching, a series of articles were published containing a fairly detailed image of Poland as an attractive tourist destination, listing historical monuments, places of interest, and entertainment venues with their rich and relatively cheap offer of multiple pleasures ["Poznan is definitely a city for nightlife," Irish Examiner, June 7, 2012; "the Old Market Square, a truly beautiful area of houses, shops, restaurants and bars" Irish Daily Mail, May 10, 2012; "Poznan is a treat, a city the visiting Irish fans will fall in love with. This may in part be down to the architecture, the good shopping.... the bustle and chatter make the square a magnet for anyone spending a few days in town" (Irish Daily Mail, May 21, 2012, Edition 1)].

The occasional negative reporting of the 2012 tournament included fears about possible xenophobia and racism, dangers of violence by Polish football hooligans, faults in the organization of the tournament, the conditions of local facilities, and rip-off accommodation prices. The negative reporting largely disappeared as the tournament commenced. Before that, there had been references to Euro 2012: Stadiums of Hate BBC Panorama programme and some articles repeated its warnings against travelling to Ukraine and Poland (Sunday Independent (Ireland), June 3, 2012; Irish Examiner, June 9, 2012), while others mentioned the alleged incident of racist chants being directed at black Dutch players (The Irish Times, June 8, 2012; Belfast Telegraph, June 8, 2012; The Mirror, June 8, 2012, Eire Edition; Irish Examiner, June 9, 2012). Several Irish journalists, however, criticized the $\mathrm{BBC}$ for the prejudiced and one-sided view of football fandom in Eastern Europe and argued that the Panorama programme, instead of giving an objective picture of Eastern Europe, actually exposed English xenophobia and a deeply entrenched ethnic bias. Sunday Independent argued that "Poznan and Gdansk are proud old cities... they deserve the type of respect the Irish football fan has always shown when abroad" and that "Poland is the same as anywhere else in the world. Every city has an underbelly. If you go looking for it (the way BBC's Panorama did so diligently with their documentary), you will find it" (Sunday Independent, Ireland, June 3, 2012).

Anyway, negative reporting of the intercultural encounters during Euro 2012 was marginal compared to the overall positive assessment offered in a majority of articles. The Irish newspapers despaired about the sporting failure of Ireland national team, but presented Euro 2102 as a sports festival which gave the 
estimated 70,000 travelling fans a chance to confront ethnic differences and find them easy to accommodate. The press reporting became another channel for the intensification of intercultural contact for Irish newspaper readers. The Irish press made use of such strategies which framed the UEAFA football tournament as a mega-sport event with significant positive consequences for Irish-Polish cultural contact.

\section{Conclusions}

The conclusions from the analyses of the two press corpuses, although quite different from the point of view of intercultural contact, point to the operation of similar media mechanisms. It seems that the failure of the British press to identify areas of cultural affinity of the hosts and guests of the football tournament resulted from two related factors, which have been also observed in the earlier research concerning media representations of Poland in the British press (Wawrzyczek et al. 2010). The first was the narrow focus on easy in-group communication with the target readers by playing up to their historically determined, deeply rooted xenophobic stereotypes of cultural and civilization backwardness of Eastern Europe that go back to the times of World War II, the Cold War divisions and have been refreshed by the recent problematic experience of massive EU labour migrations (Wawrzyczek et al. 2010). Second is the news media process of hybridization between entertainment and factual journalism known as infotainment, which requires spiking serious or pallid information about events and places with funny content and soft topics like celebrity gossip, and scandal.

Similar media mechanisms produced a different cultural effect in the Irish press. The largely positive account of the Polish-Irish intercultural encounter, which was related not only to the experience of the fans in Poznań, but also in other cities, such as Gdańsk, Bydgoszcz, and Torun, was facilitated by the use of clichéd generalizations about the two nations, i.e. the formulaic, mythical and heavily gendered narratives of national identity as well as stereotypes about them. The Irish press demonstrated a tendency to include amusing and feel-good content, even in the face of Ireland's sporting failure in the tournament. While the coverage stressed the success of Euro 2012 in bringing Poles and the Irish closer, the intercultural contact it represented was rather simplified and incomplete.

The presented analyses suggest that the interculturality of sports mega events should be studied as part of the general process of mediatization, that is a "process through which core elements of a social or cultural activity [...] assume media form" (Hjarvard 2008: 13-14). The media have grown to be a relatively 
autonomous social institution essential for the activities of other non-media social bodies and organizations (Lövheim, Lundby 2013), and sports is no exception to this process. The present study demonstrated that the British and Irish newspaper content on Euro 2012 was governed predominantly by media logic and interest, rather than other criteria of news selection and communication such as, for instance, promoting intercultural dialogue. Thus, when it comes to organization of sporting events and the shaping of their publicity, the involved institutions - the states, the international sports associations and their public relations agencies - need to construct them according to the criteria to which the media would be most responsive. Knowledge of past experiences of peoples or groups and understanding their conventionalized thinking habits may help predict what information is likely to be socially, politically and culturally significant for their media. A carefully planned media management strategy based on such awareness is necessary not only to anticipate and prevent negative coverage, but also to make sport events truly intercultural.

\section{Bibliografia}

1. Aman, Robert, 2014, Impossible Interculturality? Education and the Colonial Difference in a Multicultural World. Linköping: Linköping University.

2. Bairner, Alan, 2001, Sport, Nationalism, and Globalization: European and North American Perspectives. Albany: State University of New York Press.

3. Barrett, Martyn, ed., 2013, Interculturalism and multiculturalism: similarities and differences. Strasbourg: Council of Europe Publishing.

4. Barska, Anna, Marek Korzeniowski, eds., 2007, Wielokulturowość - międzykulturowość - transkulturowość w perspektywie europejskiej i pozaeuropejskiej. Opole: Wydawnictwo Uniwersytetu Opolskiego.

5. BBC ONE Panorama, 2012, Euro 2012: Stadiums of Hate. Available from http://www. bbc.co.uk/programmes/b01jk4vr. [ 05.05. 2014].

6. Cai, Deborah A., José I. Rodríguez, 1996-7, "Adjusting to Cultural Differences: The Intercultural Adaptation Model." Intercultural Communication Studies, VI (2), 1-17.

7. Council of Europe. (n.d) Intercultural Dialogue. Available from: www.coe.int $/ t / d g 4 /$ intercultural/concept_EN.asp. [ 30.06.2015].

8. Dashper, Katherine, Thomas Fletcher, Nicola McCullough, eds., 2014, Sports Events, Society and Culture. London: Routledge.

9. Dervin, Fred, Anahy Gajardo and Anne Lavanchy, eds., 2011, Politics of Interculturality. Newcastle upon Tyne: Cambridge Scholars Publishing. 
10. Dmowski, Seweryn, Aleksander Szałański, 2012, "Globalna gra. Futbol jako czynnik w stosunkach międzynarodowych" (The global game. Football as a factor in international relations). Społeczeństwo i Polityka, No. 2 (31), 137-162.

11. Falkheimer, Jesper, 2007, "Events Framed by the Mass Media: Media Coverage and Effects of America's Cup Preregatta in Sweden." Event Management, 11, 1-8.

12. Fowler, Roger, 1991, Language in the News: Discourse and Ideology in the Press. London: Routledge.

13. Getz, Donald, 2012, Event Studies: Theory, Research and Policy for Planned Events. London: Routledge.

14. Gonçalves, Susana, Markus A. Carpenter, eds., 2013, "Preface”. In: Susana Gonçalves, Markus A. Carpenter eds. Diversity, Intercultural Encounters, and Education. New York and Milton Park: Routledge, xi-xix.

15. “Interculturality". (n.d.) Available from: www.lmg.ulg.ac.be/articles/intercult_en.html\#ancre74676. [29.06.2015].

16. Hjarvard, Stig, 2008, "The mediatization of religion. A theory of the media as agents of religious change." Northern Lights, 6, 9-26. http://dx.doi.org/10.1386/nl.6.1.9_1

17. Horne, John, Wofram Manzenreiter, 2006, "Sports Mega-Events: Social Scientific Analyses of a Global Phenomenon." Sociological Review, Vol. 54, No. Suppl. 2, 1-187.

18. Koegeler-Abdi, Martina and Richard Parncutt, 2013, "Introduction". In: Martina Koegeler-Abdi and Richard Parncutt, eds. Interculturality: Practice meets Research. Newcastle upon Tyne: Cambridge Scholars Publishing, 1-11.

19. Lavanchy, Anne, Anahy Gajardo and Fred Dervin, 2011, "Interculturality at Stake". In: Fred Dervin, Anahy Gajardo and Anne Lavanchy, eds. Politics of Interculturality. Newcastle upon Tyne: Cambridge Scholars Publishing, 1-28.

20. Lövheim, Mia, Knut Lundby, 2013, "Mediated Religion across Time and Space: A Case Study of Norwegian Newspapers." Nordic Journal of Religion E Society, Vol. 26, Issue 1, 25-43.

21. Maguire, Joseph, 2005, Power and Global Sport: Zones of Prestige, Emulation and Resistance. Abingdon and New York: Routledge.

22. Manzenreiter, Wolfram and Georg Spitaler, 2010, "Introduction: Governance, Citizenship and the New European Football Championships: the European Spectacle." Soccer E Society, Vol. 11, No. 6, 695-708. http://dx.doi.org/10.1080/14660970.201 0.510725

23. Otten, Matthias, 2009, "Academicus interculturalis? Negotiating interculturality in academic communities of practice." Intercultural Education, Vol. 20, No. 5, 407-417. http://dx.doi.org/10.1080/14675980903371266

24. Piller, Ingrid, 2011, Intercultural Communication: A Critical Introduction. Edinburgh: Edinburgh University Press.

25. Rattanasi, Ali, 2011, Multiculturalism: A Very Short Introduction. Oxford: Oxford University Press. 
26. Richards, Greg, Marisa de Brito, Linda Wilks, eds., 2013, Exploring the Social Impacts of Events. London: Routledge.

27. Richardson, John E., 2007, Analysing Newspapers: An Approach from Critical Discourse Analysis. Houndmills and New York: Routledge.

28. Roche, Maurice, 2000, Mega-events and Modernity: Olympics and Expos in the Growth of Global Culture. London: Routledge.

29. Rozbicki, Michal Jan, 2015, "Introduction - Intercultural Studies: The Methodological Contours of asn Emerging Discipline.” In: Michal Jan Rozbicki, ed. Perspectives on Interculturality: The Construction of Meaning in Relationshops of Difference. New York: Palgrave MacMillan, 1-23.

30. Scollon, Ron, Suzanne Wong Scollon, Rodney H. Jones, 2012, "Preface to the Third Edition." In: Intercultural Communication: A Discourse Approach. Malden and Oxford: John Wiley \& Sons, 3rd Edition.

31. Shoemaker, Pamela J. and Akiba A. Cohen, 2006, News Around the World: Content, Practitioners, and the Public. New York and London: Routledge.

32. SKY SPORTS NEWS, 2012, Euro 2012 Special Report-Ukraine's Hooligans. Available from: http://www1.skysports.com/watch/video/tv-shows/special-report/7759643/ special-report---14th-may. [25.06. 2015]

33. Szerląg, Alicja, ed., 2013, Wielokulturowość - międzykulturowość w edukacji akademickiej. Ku nowej jakości kształcenia. Wrocław: Oficyna Wydawnicza ATUT.

34. Śliz, Anna, Marek S. Szczepański, 2011, „Wielokulturowość i jej socjologiczny sens. Festival caravan czy wielokulturowe street party?" (Sociological Sense of Multiculturalism. Festival Caravan or Multicultural Street Party?), Studia Socjologiczne, 4 (203), 7-25.

35. UEFA, 2013, “No to Racism”: IX. Resolution: European Football united against racism. Available from: http://www.uefa.org/social-responsibility/respect/no-to-racism/index.html. [01.07.2015].

36. Van Dijk, Teun A., 2001, “Critical Discourse Analysis.” In: Tannen, D. Schiffrin \& H. Hamilton, eds. Handbook of Discourse Analysis. Oxford: Blackwell, 352-371.

37. Wawrzyczek, Irmina, Zbigniew Mazur, Hanna Szewczyk, Alan Bairner, 2010, Oswajanie Innego. Obraz Polski i Polaków w prasie brytyjskiej w latach 2002-2007. Lublin: Wydawnictwo Gaudium.

38. Wodak, Ruth \& Michael Meyer, eds., 2006, Methods of Critical Discourse Analysis. London: Sage.

Summary: Sport is considered the epitome of interculturality in action due to its ability to bring people together in unison and generate discord at the same time. This peculiar nature of sport is also reflected in the media coverage of sport events. The present study analyses the British and Irish press coverage of the 2012 UEFA European Championship (Euro 2012) finals held in Poland and Ukraine as an example of a mediated practice of intercultural engagement. The tenor of the reporting was found to be remarkably different in the newspapers produced 
Pobrane z czasopisma Artes Humanae http://arteshumanae.umcs.pl

Data: 26/04/2023 15:23:33

in two neighbouring countries and often owned by the same media corporations. The British press failed to identify areas of cultural affinity of the hosts and guests of the tournament by playing up to the readers' xenophobic stereotypes of cultural and civilization backwardness of Eastern Europe. The depiction of the Polish-Irish intercultural encounter by the Irish press, while largely positive, was also based on stereotypes and clichéd generalizations about the two nations. The study demonstrated that the British and Irish newspaper content on Euro 2012 was governed predominantly by the media own logic and interest, with little care for the quality of intercultural dialogue.

Key words: football, UEFA Euro 2012, interculturality, British press, Irish press, media representations of Eastern Europe 